\title{
Animus of the Underling: Theorizing City Diplomacy in a World Society
}

\author{
Benjamin Leffel \\ Department of Sociology, University of California Irvine (UCI), Irvine, CA \\ 92697-5100, United States \\ bleffel@uci.edu
}

Received: 20 July 2017; revised: 13 May 2018; accepted: 20 September 2018

\section{Summary}

This article explores the nature of city diplomacy using newly available archives chronicling the 'municipal foreign policy movement' of the 1980s, in which US city governments intervened directly in late Cold War foreign affairs issues. Cases covered include US city governments' involvement in the nuclear free zone movement, the Central American crisis and the anti-Apartheid movement throughout the 1980s. A theoretical synthesis of literature in world society theory, diplomatic studies and social movement theory is used to explain the normative, macro-sociological, legal, democratic and sociopolitical dynamics of contentious city-government intervention in foreign affairs. Emphasizing the normative processes at play, this article argues through a world society theoretical interpretation that 'municipal foreign policy' efforts represent local-level codification of universal norms that the US federal government either neglected to enforce or directly violated.

\section{Keywords}

city diplomacy - norms - world society - US politics - Cold War - social movements democracy - sub-state actors 


\section{Introduction $^{1}$}

The study of city diplomacy may find a rich analytical resource in observing the foreign affairs involvements of American city governments throughout the 1980 . This period saw municipal activism significantly more potent than what had been seen during the Vietnam War, in which city governments intervened directly in foreign policy issues in defiance of the federal government, a series of activities that came to be known colloquially as the municipal foreign policy movement. ${ }^{2}$ At the forefront of this movement was the former Irvine, California-based Center for Innovative Diplomacy (CID), which maintained a network of over 6,ooo US local officials and activists concerned with a range of foreign-policy issues. CID's flagship publication, the Bulletin of Municipal Foreign Policy (hereafter, the Bulletin), is understood to contain the most consistent and comprehensive coverage of this movement. ${ }^{3}$

In 2016, former Irvine, California, mayor Larry Agran and I collected and archived these materials into the California Digital Archive, making them accessible online for the first time in full. ${ }^{4}$ This article draws from these newly available materials of well-documented cases of US 'municipal foreign policies' in three foreign affairs issue-areas: the establishment of 'nuclear free zones' (NFZs); the sending of aid to and declaration of sanctuary status for refugees from Central America; and divesting from Apartheid South Africa. In the absence of available quantifiable data in city diplomacy research, a qualitative analytical approach is most appropriate. ${ }^{5}$ The majority of Bulletin articles reported interviews with or were written by city official correspondents themselves, offering accounts of events that are sufficiently detailed to analyse the motivations and views of city-level actors. This sourcing also alleviates concern over potential editorial bias in the materials. A review of both the relevant

1 The author dedicates this work to Richard V. Knight, a scholar, mentor and friend. The author is grateful to the funding provided by the Kugelman Citizen Peacebuilding Research Fellowship, Center for Citizen Peacebuilding, at the University of California Irvine. The author would also like to thank the scholars who provided valuable input on previous drafts of this work at the University of California Irvine, the University of Oxford and the University of Southern California.

2 P.J. Spiro, 'Taking Foreign Policy Away from the Feds', Washington Quarterly, vol. 11, no. 1 (1988), pp. 191-203.

3 A. Kirby, S. Marston and K. Seashoals, 'World Cities and Global Communities: The Municipal Foreign Policy Movement and New Roles for Cities', in P.L. Knox and P.J. Taylor (eds), World Cities in a World System (New York: Cambridge University Press, 1995), p. 273.

4 See https://escholarship.org/uc/uci_cid.

5 A.S. Kuznetsov, Theory and Practice of Paradiplomacy: Subnational Governments in International Affairs (New York: Routledge, 2015). 
literature and the above-mentioned archives warrants a conceptual focus for this study on the role of norms in politically contentious city diplomacy.

Economist and urban affairs scholar Richard V. Knight once argued that accelerated globalization has given rise to a new global society defined by 'a global consciousness and a global ethic', ${ }^{6}$ an argument that the Bulletin itself adopted as an early theoretical explanation for the social forces driving the municipal foreign policy movement. ${ }^{7}$ Over time, other scholars also came to argue that the emergence of a global consciousness influenced the municipal foreign policy movement, particularly as globalization increasingly threatened the legitimacy of the nation-state. ${ }^{8}$ From this context, city governments increasingly came to be purveyors and defenders of universal values such as human rights, ${ }^{9}$ which may be understood as an outgrowth of Kantian universalism, where an international society creates moral imperatives limiting the actions of states in international affairs. ${ }^{10}$

The process began in the 1980 s of US city governments gaining a more pronounced role as actors in this norm-driven international society, ${ }^{11}$ for which the case of the municipal foreign policy movement is instructive. An oft-repeated theme throughout the Bulletin was that activist US local officials passing antiApartheid divestment laws and other municipal foreign policies did so in order to 'accelerate national and international reform, ${ }^{12}$ specifically reform towards greater adherence to universal norms. US local officials were reported to have actively 'embraced the Nuremberg principle that "the fact that a person acted pursuant to the order of his Government or of a superior does not relieve him from responsibility under international law" and believe that they have a duty

$6 \quad$ R.V. Knight, 'The Emergent Global Society', in R.V. Knight and G. Gappert (eds), Cities in a Global Society (London: SAGE, 1989), p. 25.

7 W. Swaim, 'Why Municipal Foreign Policy is Sexy', Bulletin of Municipal Foreign Policy (hereafter, Bulletin), vol. 4, no. 1 (1989-1990), pp. 6-8; W. Swaim, 'A City Hall Guide to the Future', Bulletin, vol. 4, no. 1 (1989), pp. 62-63.

8 Kirby et al., 'World Cities and Global Communities'.

9 B. Barber, If Mayors Ruled the World: Dysfunctional Nations, Rising Cities (New Haven, CT: Yale University Press, 2013); and N. Cornago, 'On the Normalization of Sub-State Diplomacy', The Hague Journal of Diplomacy, vol. 5 (2010), pp. 11-36.

10 H. Bull, 'Does Order Exist in World Politics?', in P.R. Viotti and M.V. Kauppi (eds), International Relations Theory: Realism, Pluralism, Globalism and Beyond (Needham Heights, MA: Allyn \& Bacon, third edition, 1999), pp. 127-129.

11 S. Curtis, Global Cities and Global Order (Oxford: Oxford University Press, 2016); J. Kincaid, 'Rain Clouds over Municipal Diplomacy: Dimensions and Possible Sources of Negative Public Opinion', in E. Fry, L. Radebaugh and P. Soldatos (eds), The New International Cities Era: The Global Activities of North American Municipal Governments (Provo, UT: Brigham Young University Press, 1989), pp. 223-250.

12 J. Sklansky, 'CFCs Days are Numbered', Bulletin, vol. 3, no. 4 (1989), pp. 8-12. 
to adhere to international norms and laws.' ${ }^{13}$ The prominent role of norms throughout this movement thus warrants a focus on normative processes in the municipal foreign policy movement, while also accounting for other equally important social forces.

Accordingly, the sections below will use strands of complementary literature: first from diplomatic studies to explain the legal and democratic governance underpinnings of municipal foreign policy; second from social movement theory to explain the broader activist dynamics surrounding cities; and third from world society theory to explain the normative processes of municipal foreign policy and their macro-sociological context.

\section{Diplomacy Studies and Municipal Foreign Policy}

Diplomacy studies literature on the foreign relations of non-central governments includes 'city diplomacy', 'sub-state diplomacy', 'subnational diplomacy' and 'paradiplomacy', 14 describing the global involvement of municipal governments, of state/provincial or otherwise non-central governments and of nonstate actors engaged in diplomatic affairs parallel to that of states. This article is interested in city diplomacy, in which local elected officials are the actors of interest. ${ }^{15}$

When addressing the US context of city diplomacy, these strands of literature emphasize democracy, legal structure and decentralization. Legally, while local governments cannot enter into treaties, they can sign agreements and make political declarations, which are ultimately aimed at welfare for their local citizens. ${ }^{16}$ Unique to city governments is local legislative power that allows them to affect consequential foreign affairs outcomes, somewhat mirroring that of nation-states. ${ }^{17}$ As will be argued in this article, this advantage allowed for US city governments to codify universal norms during the

13 M. Shuman, 'Why Cities are Entering International Affairs: An Overview', Bulletin, vol. 1, no. 1 (1986), pp. 3-4.

14 D. Criekmans, 'Regional Sub-State Diplomacy from a Comparative Perspective: Quebec, Scotland, Bavaria, Catalonia, Wallonia and Flanders', The Hague Journal of Diplomacy, vol. 5, no. 1 (2010), pp. 37-64; F. Nganje, 'The Developmental Paradiplomacy of South African Provinces: Context, Scope and the Challenge of Coordination', The Hague Journal of Diplomacy, vol. 9 (2014), pp. 119-149.

15 Michele Acuto, 'City Diplomacy', in C.M. Constantinou, P. Kerr and P. Sharp (eds), The SAGE Handbook of Diplomacy (Thousand Oaks, CA: SAGE, 2016), pp. 510-520.

16 R. Tavares, Paradiplomacy: Cities and States as Global Players (New York: Oxford University Press, 2016).

17 Criekmans, 'Regional Sub-State Diplomacy'. 
municipal foreign policy movement, including the use of zoning authority to establish NFZs and sanctuary cities. However, this legal autonomy varies in cities of different countries, as constitutional structure, the political nature of government and other related restrictions can enable or constrain city-level activity in foreign affairs. ${ }^{18}$

States that place constitutional limitations on or lack clear constitutional provisions for such competencies, such as Brazil and South Africa, respectively, tend to constrain city diplomacy, ${ }^{19}$ while democratic and federal systems like Belgium and the United States tend to allow local authorities to gain greater autonomy and thus competency in foreign affairs. ${ }^{20}$ Research for this article is situated in the democratic context of the latter, given that the municipal foreign policy movement took place in the United States. Robert Dahl and Edward Tufte once argued that 'rather than conceiving of democracy as located in a particular kind of inclusive sovereign unit, we must learn to conceive of democracy spreading through a set of interrelated political systems [...] none of which is sovereign'.21 The late international relations scholar Chadwick Alger, himself on the Bulletin's editorial board, argued that the municipal foreign policy movement was as an implicit response to Dahl and Tufte's appeal, and beckoned scholars to find suitable rules to apply among a variety of nonsovereign units in a democracy. ${ }^{22}$

Decentralization is another important underpinning of municipal foreign policy. Through the late 1970s and early 1980s, US presidents Richard Nixon and Ronald Reagan's 'new federalism' conferred greater responsibilities upon state and local authorities, including managing growing numbers of SouthEast Asian refugees, establishing footholds in overseas markets, and problems posed by oil prices and petrol shortages, often in the absence of any federal policy. ${ }^{23}$ Coupled with other foreign affairs concerns, such as Reagan's

18 Tavares, Paradiplomacy.

19 Nganje, 'The Developmental Paradiplomacy'; and J. Setzer, 'Testing the Boundaries of Subnational Diplomacy: The International Climate Action of Local and Regional Governments', Transnational Environmental Law, vol. 4, no. 2 (2015), pp. 1-19.

20 P. Bursens and Jana Deforche, 'Going Beyond Paradiplomacy? Adding Historical Institutionalism to Account for Regional Foreign Policy Competences', The Hague Journal of Diplomacy, vol. 5, no. 2 (2010), pp. 151-171.

21 R. Dahl and E.R. Tufte, Size and Democracy (Stanford, CA: Stanford University Press, 1973), p. 135 .

22 C. Alger, 'The World Relations of Cities: Closing the Gap between Social Science Paradigms and Everyday Human Experience', International Studies Quarterly, vol. 34 (1990), pp. 493-518.

23 B. Hocking, Localizing Foreign Policy: Non-Central Governments and Multi-Layered Diplomacy (New York: St Martin's Press, 1993); and Tavares, Paradiplomacy. 
involvement in Central America and the nuclear arms race with the Soviet Union, US city intervention in foreign affairs accelerated significantly. This response may be understood as what Alexander Kuznetsov calls the 'central government's insufficient effectiveness in foreign relations' motivation for city diplomacy. ${ }^{24}$ It may also be understood in terms of Noé Cornago's concept of plural diplomacies, which explains that among other forces, a normative desire for peace can prompt local governments and other non-state actors to mobilize and pursue diplomatic goals. ${ }^{25}$

On local governments specifically, Kristin Ljungkvist argues that local-level identification with the global community can lead to discourse between local officials and constituents on global issues, resulting in the formation of global interest and ultimately city-government intervention in foreign affairs - a process that is accelerated when the nation-state fails in foreign relations. ${ }^{26}$ Yet these local official-constituent dialogues, and whether they result in municipal foreign policy, are conditioned by forces explained by social movement theory, discussed in the next section.

\section{Social Movement Theory and Municipal Foreign Policy}

Social movement theory elucidates the larger environment of social action by non-state actors in which activist US city governments were embedded in the 1980s, and also shows that the municipal foreign policy movement was not a single movement per se, but was rather a movement within movements. Social movements during this period that challenged the nation-state on foreign affairs, such as the anti-Apartheid movement, involved grassroots activists from the public, private and civic sectors who were motivated by 'a shared global morality and the assertion of universal norms.' ${ }^{27}$ Specifically, new social movement theory explains post-196os' social movements in advanced capitalist societies like the United States as post-industrialist in nature,

24 Kuznetsov, Theory and Practice of Paradiplomacy.

25 N. Cornago, Plural Diplomacies: Normative Predicaments and Functional Imperatives (Leiden: Martinus Nijhoff, 2013).

26 K. Ljungkvist, The Global City 2.o: From Strategic Site to Global Actor (New York: Routledge, 2015).

27 G. Seidman, 'Adjusting the Lens: What Do Globalizations, Transnationalism, and the Anti-apartheid Movement Mean for Social Movement Theory?', in J.A. Guidry, M.D. Kennedy and M.N. Zald (eds), Globalizations and Social Movements: Culture, Power, and Transnational Public Sphere (Ann Arbor, MI: University of Michigan Press, 200o), pp. 339-358. 
appealing less to economic survival than to personal responsibility for a collective future. ${ }^{28}$ Movements of this era were less seeking greater power, but greater autonomy, ${ }^{29}$ and were driven by universalistic moral and ethical concerns. ${ }^{30}$ New social movement theory has been used to explain the NFZ and anti-Apartheid movements, stressing that the moral-philosophical context empowered local actors to assert their stance on international security matters, which among city governments manifested as the establishment of NFZs and divestment from Apartheid South Africa. ${ }^{31}$ Yet not all US city governments became NFZs, divested from Apartheid South Africa, or provided support for Central Americans in crisis. Further requirements for such city-government mobilization was proper frame alignment and local political leanings, which can be explained by framing theory and the political process theory of social movements.

Framing theory holds that social movements are most successful when the interpretive frames of a cause projected by social movement organizations are aligned with the interpretive frames of participants, and, as such, 'frame alignment' is required for the successful mobilization of constituents and recruitment of new ones. ${ }^{32}$ For example, NFZ measures in cities around the world were often accompanied by local campaigns to educate other communities about the dangers of the arms race, ${ }^{33}$ framing the cause as concerned with local safety. In the United States, the Center for Innovative Diplomacy itself did

28 Z. Hegedus, 'The Challenge of the Peace Movement: Civilian Security and Civilian Emancipation', Alternatives XII (1987), pp. 197-216; and Z. Hegedus, 'Social Movements and Social Change in Self-Creative Society: New Civil Initiatives in the International Arena', International Sociology, vol. 4, no. 1 (1989), pp. 19-36.

29 A. Melucci, Nomads of the Present (London: Hutchinson Radius, 1989); A. Melucci, Challenging Codes (Cambridge: Cambridge University Press, 1996); and S.M. Buechler, 'New Social Movements and New Social Movement Theory', in D.A. Snow, D. Porta, B. Klandermans and D. McAdam (eds), The Wiley-Blackwell Encyclopedia of Social and Political Movements (Hoboken, NJ: Blackwell Publishing Ltd., 2013).

30 S. Crook, J. Pakulski and M. Waters, Postmodernization: Change in Advanced Society (London: SAGE, 1992).

31 Hegedus, 'Social Movements and Social Change in Self-Creative Society'.

32 D.A.Snow, E. Rochford, S. Worden and R. Benford, 'Frame Alignment Processes, Micromobilization, and Movement Participation', American Sociological Review, vol. 51, no. 4 (1986), pp. 464-481; D.A. Snow and R. Benford, 'Ideology, Frame Resonance and Participant Mobilization', International Social Movement Research, vol. 1 (1988), pp. 197-217.

33 Nuclear Free America, 'Nuclear-Free-Zone Communities Now Exceed 3,80o Worldwide', Bulletin, vol. 2, no. 1 (1988), p. 36. 
the same among US local government officials, educating on nuclear security risks, as well as on how to establish NFZs. ${ }^{34}$

Social movement organizations in the United States projected personalized accounts of atrocities committed by Nicaraguan Contras, the assassination of Archbishop Oscar Romero in El Salvador, as well as other events. These narratives resonated in a variety of ways among Americans, with Christians relating in spiritual terms to the plight of victims, and the need to cease violence broadly resonating with peace-activist communities. ${ }^{35}$ The resultant frame alignment prompted American communities of faith, peace activists and other groups to commit to not tolerating violations of human rights norms and to forging new supportive ties with Central American counterparts. ${ }^{36}$ Similarly, organizations advocating for divestment from Apartheid South Africa, such as TransAfrica, helped link the narrative of racism in Apartheid to support for or tolerance of racism in the United States, which policy-makers became sensitive to over time. ${ }^{37}$

While new social movement theory and framing theory explain the mobilization of non-state actors in both civil society and local government, the distinctive city-government diplomacy of the municipal foreign-policy movement can be understood through the 'political process' theory of social movements. This theory holds that in order for movements challenging nation-state policy to mobilize successfully, the appropriate political opportunities must be present at national and local levels. ${ }^{38}$ Specifically, the Reagan administration's bellicose nuclear security policies towards the Soviet Union provoked a wave of dissidence in the United States and beyond, ${ }^{39}$ and at the local level, when both

34 Alger, 'The World Relations of Cities'; and M. Shuman, 'Dateline Main Street: Local Foreign Policies', Foreign Policy, vol. 65 (1986), pp. 154-174.

35 S.E. Nepstad, 'Creating Transnational Solidarity: The Use of Narrative in the US-Central America Peace Movement', Mobilization: An International Journal, vol. 6, no. 1 (2001), pp. 21-36.

36 G.L. Wiltfang and D. McAdam, 'The Costs and Risks of Social Activism: A Study of Sanctuary Movement Activism', Social Forces, vol. 69, no. 4 (1991), pp. 987-1010.

37 A. Klotz, 'Norms Reconstituting Interests: Global Racial Equality and US Sanctions against South Africa', International Organization, vol. 49, no. 3 (1995), pp. 451-478.

38 D. McAdam, Political Process and the Development of Black Insurgency (Chicago, IL: University of Chicago Press, 1982); D. McAdam, 'Political Process Theory', in D.A. Snow et al. (eds), The Wiley-Blackwell Encyclopedia; D. McAdam, J.D. McCarthy and M.N. Zald (eds), Comparative Perspectives on Social Movements: Political Opportunities, Mobilizing Structures, and Cultural Framings (New York: Cambridge University Press, 1996); and S. Tarrow, Struggle, Politics and Reform: Collective Action, Social Movements and Cycles of Protest (Ithaca, NY: Cornell University Center for International Studies, 1989).

39 D.S. Meyer, 'Protest Cycles and Political Process: American Peace Movements in the Nuclear Age', Political Research Quarterly, vol. 47 (1993), pp. 451-479. 
city-government leaders and their local constituents were politically aligned on peace activism, city governments declared their jurisdictions NFZs, as was the case for Cambridge, Massachusetts. ${ }^{40}$ Cities where this political alignment does not occur preclude involvement in municipal foreign policy, as demonstrated in the case of Seattle, where local officials passed a sanctuary-city measure in 1986, but soon thereafter rescinded it because of strong disagreement from local constituents. ${ }^{41}$ This explanation may similarly be extended to other jurisdictions on the issues of responding to the Central American crisis and divestment from Apartheid South Africa.

In sum, these strands of social movement theory show that the universalistic post-industrial values of 1980 s' $^{\prime}$ America combined with ontological narratives of certain transnational issues, resonating with countless civil-society and community groups, stoking social movements and activism to redress those issues. Action specifically by city governments on these transnational issues additionally required that the political leanings of constituents and local officials were aligned on said issues, a condition that when satisfied led to the city diplomacy that is distinctive of the municipal foreign-policy movement. While legislative power was a novel advantage possessed by city governments compared to other social movement actors, it is uncertain which of the two types of actors exerted greater pressure upon the federal government. While the above diplomatic studies and social movement literature provide some insight as to normative processes, they lack a more systemic, macro-sociological framework in which to understand the function of norms. The following sections introduce world society literature as a framework for understanding municipal foreign policy as global norm enforcement by city governments, followed by individual cases that connect this framework to municipal foreign policy.

\section{World Society Theory and Municipal Foreign Policy}

World society theory is a sociological institutionalist theory that describes the process by and institutional mechanisms through which universal norms diffuse globally. The world society itself is a global-scale cultural context in

40 B. Miller, 'Political Empowerment, Local-Central State Relations, and Geographically Shifting Political Opportunity Structures: Strategies of the Cambridge, Massachusetts, Peace Movement', Political Geography, vol. 13, no. 5 (1994), pp. 393-406.

41 I. Bau, 'Cities of Refuge: No Federal Preemption of Ordinances Restricting Local Government Cooperation with the INS', Berkeley La Raza Law Journal, vol. 7, no. 1 (1994), pp. 50-71; and M. Hughes and D. Phalen, 'Seattle Voters Rescind City of Refuge Status', Bulletin 1, no. 1 (1986), p. 21. 
which actors are embedded, a context that shapes the identities and actions of actors and the institutional structures through which they operate..$^{42}$ Norms and practices of human rights, science, governance and other areas initially emanate largely from Western countries like the United States and then diffuse globally through supranational institutions such as the United Nations (UN). ${ }^{43}$ The resultant world culture that diffuses therein exogenously influences both the identity of nation-states and the norms that they are expected to enforce, although conformity varies cross-nationally. ${ }^{44}$ That is, conformity is more rapid in nations that are relatively more embedded in the world society through greater membership in various international associations, among other factors. ${ }^{45}$ World society theorists tend to emphasize international nongovernmental organizations (INGOS), such as the Red Cross or a range of other issue-focused groups, as the key actors facilitating the diffusion of world society norms to nation-states, down to subnational units and to the individual level. ${ }^{46}$ The greater the number of membership ties to INGOs held by citizens of a given nation, the more likely and rapidly this nation conforms to global norms ${ }^{47}$ ING OS, but also other entities such as universities, can serve as 'receptor sites' that receive, decode and transmit norms from world society to national government institutions, which then can yield policy outcomes. ${ }^{48}$

In the pre-Second World War era, diplomatic ties at the national level were more important, but INGOs emerged as a distinct and significant node

42 J.W. Meyer. 'World Society, Institutional Theories, and the Actor', Annual Review of Sociology, vol. 36, no. 1 (2010), pp. 1-20.

43 W. Longhofer and E. Schofer, 'National and Global Origins of Environmental Association', American Sociological Review, vol. 75, no. 4 (2010), pp. 505-533; J.W. Meyer, J. Boli, G.M. Thomas and F.O. Ramirez, 'World Society and the Nation-State', American Journal of Sociology, vol. 103, no. 1 (1997), pp. 144-181; and E. Schofer, 'Cross-National Differences in the Expansion of Science, 1970-199o', Social Forces, vol. 83, no. 1 (2004), pp. 215-248.

44 J.A. Guidry, 'The Useful State? Social Movements and the Citizenship of Children in Brazil', in Guidry et al., Globalizations and Social Movements, pp. 147-182.

45 Meyer, 'World Society, Institutional Theories'.

46 J. Givens and A. Jorgenson, 'Individual Environmental Concern in the World Polity', Social Science Research, vol. 42 (2013), pp. 418-431; G. Drori, and E. Schofer, A. Hironaka, D.J. Frank and W. Longhofer, 'Sociological Institutionalism and World Society', in K. Nash, A. Scott and E. Amenta (eds), The Wiley-Blackwell Companion to Political Sociology (Hoboken, NJ: Blackwell Publishing, Inc., 2012), pp. 57-68.

47 J. Boli and G.M. Thomas, Constructing World Culture: International Non-Governmental Organizations since 1875 (Stanford, CA: Stanford University Press, 2000).

48 D.J. Frank, A. Hironaka and E. Schofer, 'The Nation-State and the Natural Environment over the Twentieth Century', American Sociological Review, vol. 65, no. 1 (2000), pp. 96116; and G. Krucken and F. Meier, 'Turning the University into an Organizational Actor', in G. Drori, J.W. Meyer and H. Hwang (eds), Globalization and Organization: World Society and Organizational Change (Oxford: Oxford University Press, 2006), pp. 241-257. 
of influence in the post-Second World War era, becoming a key mechanism through which Western-style geological science, ${ }^{49}$ ecology and other natural sciences have diffused globally. ${ }^{50}$ These developments represent a decentralization of 'actorhood', defined by a vast expansion of sub- and non-state actors assuming international norm-transmission roles that previously were assumed mainly or only by state actors. ${ }^{51}$ Although world society theorists have paid only limited attention to subnational authorities such as city governments, instead focusing more on INGOs, the work that has been done nevertheless provides an important means of understanding the normative processes of city diplomacy. Subnational actors, including city governments, are understood in world society literature as actors embedded within the domestic context of the nation-state, receiving, enforcing and further diffusing world society norms that is, as institutional agents such as the UN or INGOs transmit cultural meanings and discourses across the national and subnational levels, allowing world society norms to reach and exogenously influence locales. ${ }^{52}$ However, as a result of these direct connections formed between local actors and world culture, if a nation-state violates or neglects to enforce universal norms, then subnational entities may try to carry out or enforce conformity to those norms. ${ }^{53}$

This crucial yet under-studied facet of world society theory provides a compelling macro-sociological context for the role of norms in municipal foreign policy. For instance, the chair of the Berkeley, California, Commission on Peace and Justice told the Bulletin that the UN Charter and Nuremberg Principles 'establish norms of conduct for everyone in the United States, including national and local government officials' and that every municipal foreign-policy effort was also 'an effort to help enforce the Charter and the Principles'. ${ }^{54}$ In enacting municipal foreign policies, US city leaders thus acted on an understanding that 'cities can help enunciate, develop and codify international norms that can be the basis for effective international law'. 55 Via a world society interpretation, US federal government foreign-policy failures, such as incitement of

49 E. Schofer, 'The Global Institutionalization of Geological Science, 1800-199o', American Sociological Review, vol. 68, no. 5 (2003), pp. 730-759.

$50 \quad$ Frank et al., 'The Nation-State and the Natural Environment over the Twentieth Century'.

51 H. Huang, 'Planning Development: Globalization and the Shifting Locus of Planning', in Drori et al., Globalization and Organization, pp. 69-9o.

$5^{2}$ A. Hironaka, Greening the Globe: World Society and Environmental Change (New York: Cambridge University Press, 2014); and S.M. Büttner, "The World-Cultural Constitution of Regions: Subnational Regional Mobilization from a World Society Perspective', Journal of Contemporary European Studies, vol. 23, no. 2 (2015), pp. 193-207.

53 Meyer et al., 'World Society and the Nation-State'.

54 A.F. Ginger, 'From Morality to Law', Bulletin, vol. 4, no. 1 (1989), p. 3.

55 M. Shuman, 'Support Your Local State Department', Bulletin, vol. 2, no. 2 (1988), pp. 2-4. 
the Central American crisis, may thus be understood as a nation-state's failure to enforce or violation of universal norms, and the municipal foreign-policy response may be understood as the resultant local-level attempts to enforce those norms independently.

Furthermore, the United States and other Western nations exist in a regional normative context such that — with their advanced economies and high global civil-society connectivity - they are simultaneously the most prominent source, adopter and enforcer of world society norms. ${ }^{56}$ In world society terms, then, the national context of close proximity to these norms accounts for part of the reason why American cities were apt to participate in municipal foreign policy. To connect the above world society theoretical framework to municipal foreign policy, the sections below draw on the Bulletin and other sources to discuss in detail the cases of city involvement with NFZs, the Central American crisis and anti-Apartheid efforts. These cases show multiple narratives of the norm-based motivations of city officials participating in municipal foreign policy, illustrating the world society framework of city governments enforcing global norms at play. This is followed by a discussion formulating a theoretical synthesis of world society, diplomatic studies and social movement literature for studying politically contentious city diplomacy.

\section{'Renegade Local Governments': The Nuclear Free Zone Movement}

Through the early 1980 s, the Reagan administration cut large quantities of federal assistance to local food, housing, education and employment training assistance and redirected funds to the defence budget to accelerate the nuclear arms race with the Soviet Union. ${ }^{57}$ Many American cities thus found themselves economically disenfranchised by the same federal government, which was orchestrating an arms race that they felt threatened their safety. ${ }^{58}$ Cities around the world responded to the threat by passing nuclear free zone ordinances, prohibiting the production of nuclear weapons-related materials and

$5^{6}$ G. Drori, 'Governed by Governance: The New Prism for Organizational Planning', in Drori et al., Globalization and Organization, pp. 91-120; Y.S. Jang, 'Transparent Accounting as a World Societal Rule', in Drori et al., Globalization and Organization, pp. 215-248; and Meyer, 'World Society, Institutional Theories'.

57 S. Danziger and R. Haveman, 'The Reagan Budget: A Sharp Break with the Past', Challenge, vol. 24 (1981), pp. 5-13; and R. Randall and C. Wilson, 'The Impact of Federally Imposed Stress Upon Local-Government and Nonprofit Organizations', Administration \& Society, vol. 21, no. 1 (1989), pp. 3-19.

$5^{8} \quad$ Alger, 'The World Relations of Cities'. 
similar activity in their jurisdictions, and American cities followed close behind. In 1982, Garrett Park, Maryland, became the first American city to declare its jurisdiction an NFZ. ${ }^{59}$ By the decade's end, over 160 US cities had declared themselves NFZs, ${ }^{60}$ alongside over 3,800 cities worldwide. ${ }^{61}$

This movement in the United States would in large part come to be defined by the multi-level dynamics of federal-local legal disputes, as many legal battles would ensue between the US federal and local governments over NFZ ordinances. The legal language used by the federal government's parties tended to focus on national security roles and implications, while the legal language of city governments focused on moral and normative considerations that were illustrative of the world society framework. Former US Senator Jesse Helms was a harsh critic of American cities declaring themselves NFZs, calling these cities 'renegade local governments' ${ }^{62} \mathrm{~A}$ vocal critic of municipal foreign policy and frequent verbal sparring partner of the Bulletin, the US State Department's Peter Spiro argued that 'if every state had the constitutional capacity to declare itself a nuclear free zone, the federal government might find itself in a position in which it was powerless to deploy such weapons'.63

Helms also responded to American NFzs by hypothetically positing 'what if cities decided they were going to declare war on other countries?'64 Beyond such overtures on national security implications, opponents of NFZs also cited the pre-emption doctrine of the Supremacy Clause in the US Constitution, which holds that non-federal entities may not take action that is inconsistent with federal policy. ${ }^{65}$ However, because Tenth Amendment case law holds that Congress may not directly compel states or localities to enact or administer policies adopted by the federal government, ${ }^{66}$ the pro-NFZ parties won in many legal battles. ${ }^{67}$

Local officials argued that their peace activism was underpinned by postSecond World War universal values that 'encompass the horrors of the bombing

59 H.H. Hobbs, City Hall Goes Abroad: The Foreign Policy of Local Politics (Thousand Oaks, CA, and London: SAGE, 1994).

60 A. Donnay, 'Voters Approve Four New Nuclear-Free Zones', Bulletin, vol. 3 (1988), no. 1, pp. $45-46$.

61 Nuclear Free America, 'Nuclear-Free-Zone Communities Now Exceed 3,80o Worldwide'.

62 W. Swaim, 'Feds on Offense?' Bulletin, vol. 3, no. 4 (1989), pp. 22-24.

63 Spiro, 'Taking Foreign Policy Away from the Feds', p. 197.

64 W. Swaim, 'Feds on Offense?', p. 22.

65 Spiro, 'Taking Foreign Policy Away from the Feds'.

66 B.O. Hing, Immigration Sanctuary Policies: Constitutional and Representative of Good Policing and Good Public Policy,' UC Irvine Law Review, vol. 247 (2012), pp. 253-26o.

67 Shuman, 'Dateline Main Street'. 
of the civilian cities of Hiroshima and Nagasaki, ${ }^{68}$ so US cities were framed as 'taking a moral stand' by establishing NFZs 'in a shared concern for life' with the global community. ${ }^{69} \mathrm{NFZ}$ ordinances themselves were designed and adopted pursuant to the protection of local 'health, safety and public morals, ${ }^{70}$ aiming 'to raise the moral, financial and bureaucratic costs for the US government to continue the nuclear arms race. ${ }^{71}$ For instance, Oakland, California's attorney framed the local NFZ law as being 'for the benefit of the citizens and their health and safety, ${ }^{72}$ with other cities specifically cited the hazards of radioactive materials. ${ }^{73}$

The principal outcome of NFZs in the United States was political pressure exerted by locales upon the federal government to slow or freeze the arms race, ${ }^{74}$ which was argued to demonstrate that cities 'hold the prospect of creating the global norms, laws and institutions that can make disarmament possible.' ${ }^{75}$ Per the world society framework, the US federal government's acceleration of the arms race constituted the nation-state's violation of the universal norms of nuclear security and human survival, prompting local authorities to enforce conformity to those norms via NFZs. It is noteworthy that while the legal battles fought by the federal government suggest that this pressure was taken seriously, the extent to which it hastened such outcomes as the US-Soviet disarmament accords is uncertain.

\section{'Shot at By Bullets You Paid For': The Central American Crisis}

Fearing the further spread of communism, the Reagan administration responded to the pro-communist revolutions in Central America by funding anti-communist forces, including the Contra rebels in Nicaragua and anticommunist regimes in Guatemala and El Salvador. This resulted in prolonged civil wars and loss of life that many Americans saw as conflicts sponsored by their own federal government. ${ }^{76}$ For example, during a 1989 New York

68 Ginger, 'From Morality to Law'.

69 M. Kaye, 'A Moral Stand', Bulletin, vol. 4, no. 1 (1989), p. 46.

70 Shuman, 'A Tale of Two Courts', Bulletin, vol. 4, no. 3 (1990), p. 4.

71 Shuman, 'A Tale of Two Courts', pp. 4-6.

72 Swaim, 'Feds on Offense?'

73 W. Riles, and J. Vasquez, 'What May Have Been', Bulletin, vol. 4, no. 1 (1989), p. 45.

74 T. Masanz, 'As It Lay Dying', Bulletin, vol. 2, no. 4 (1988), pp. 28-30.

75 M. Shuman, 'International Institution Building: The Missing Link for Peace', The CID Report, vol. 1, no.1 (1984), p. 13 .

76 J. Vasquez, 'LEOs Question US Policy in Central America', Bulletin, vol. 2, no. 4 (1988), p. 19. 
delegation visit to its sister city in Nicaragua, Contra rebels opened fire on the delegation, nearly killing them, to which an American reverend in the delegation remarked 'it's quite an experience to be shot at by bullets you paid for'. ${ }^{7}$ Missionaries returning to the United States from service in the region were key actors who shared information with activists about the crisis and conditions in Central America, affording them 'exposure to norm-violating information' and prompting them to act. ${ }^{78}$ Per the world society framework, the Reagan administration's triggering of the Central American crisis constituted the nation-state's violation of the universal norms of human rights, evoking local efforts across the United States to enforce these norms, stoking the animus of the underling.

Burlington, Vermont, Pittsburgh, Pennsylvania, and several other cities forged sister-city relationships with Nicaraguan and El Salvadoran cities to send aid from locally raised funds and help relieve the ravages of war, ${ }^{79}$ acts that were understood in moral terms by both sides. For example, when Rochester, New York, sent aid to its Nicaraguan sister-city of El Sauce, representatives of El Sauce characterized Rochester as a 'bodyguard of the oppressed peasant', ${ }^{80}$ and in the United States, speaker pro tempore of the State Assembly of Wisconsin, the sister state to Nicaragua, stated in the Bulletin that the Reagan administration's activity in Central America was 'corrupt foreign policy' that was 'undemocratic and morally wrong', and for which US sister-city and sister-state engagement offered a 'rekindling of idealism and regaining national self-respect'.81 Another externality of the civil wars was Central American refugees fleeing to the United States in hopes of finding safe haven. By the end of 1987, 27 US cities had declared themselves sanctuary cities for Central American refugees, including the entire state of Wisconsin declaring itself a sanctuary. ${ }^{82}$ Other efforts included the city council of Denver, Colorado, passing a resolution calling for Congressional passage of legislation granting refugees temporary haven in the United States. ${ }^{83}$ In declaring his city a sanctuary

77 C. Idzik, 'The War Comes Home', Bulletin, vol. 4, no. 1 (1989-9o), p. 57.

78 C. Smith, Resisting Reagan: The US Central America Peace Movement. (Chicago, IL: University of Chicago Press, 1996).

79 N. Gotthelf, 'Madison Links Up with Arcatao, El Salvador', Bulletin, vol. 1, no. 2 (1987), p. 10.

8 H. Levine, 'Rochester Plans Water Project', Bulletin, vol. 3, no. 3 (1989), p. 16.

81 D. Clarenbach, 'Central America and Local Policy: The View from Wisconsin', Bulletin, vol. 3 , no. 4 (1989), pp. 59-6o.

82 P. Deleray, 'List of Sanctuary Cities', Bulletin, vol. 2, no. 1 (1987), p. 20; C. Weber, Visions of Solidarity: US Peace Activists in Nicaragua from War to Women's Activism to Globalization (Boulder, CO: Lexington Books, 2006).

83 R. Martinez, 'Denver Council Lends Support to Central American Refugees', Bulletin, vol. 3, no. 2 (1989), p. 12. 
city, the mayor of Detroit appealed to human rights norms: 'Mayor Young "called upon the people of the city of Detroit to reaffirm our commitment to human rights and justice, and to reaffirm the American tradition of providing refuge to persons who have fled their native country for fear of persecution". ${ }^{84}$

The multi-level dynamics of US city diplomacy towards Central America included Minnesota's governor attempting to get legal authority over the state's National Guard units in order to prevent them from participating in training exercises in Central America, but the US Supreme Court ruled that gubernatorial consent is not needed for those exercises. ${ }^{85}$ Immigration and Naturalization Services responded to Los Angeles' sanctuary-city measure status by campaigning to cut off federal funding to the city, to which Los Angeles responded by first rescinding the measure, and then reintroducing a similar measure minus the phrase 'sanctuary', ${ }^{86}$ a case common across several cities. Aside from the safe haven and material aid provided, the chief outcome of these city interventions was a strong signal to the world that city diplomacy can serve as a healthy check on ill-conceived or immoral national foreign policies. ${ }^{87}$

\section{Making a Statement with the Almighty Dollar: The Anti-Apartheid Movement}

From 1948 to 1994, the South African system of Apartheid institutionalized racial segregation, favouring whites, who led the government. In the mid-1980s, pressure from global norms for racial equality and the demands of activists resulted in economic sanctions and trade restrictions imposed on South Africa by the US Congress and the Reagan administration. ${ }^{88}$ However, as local leaders writing in the Bulletin noted, these national sanctions did not force a hard line on corporations, so cities began to use divestment measures to force the South African government to reassess the costs that it was willing to pay to continue Apartheid. ${ }^{89}$

84 M. Ravitz, 'Detroit Becomes 27th Sanctuary City', Bulletin, vol. 2, no. 1 (1987), p. 20.

85 L. Greenhouse, 'No to Perpich', Bulletin, vol. 4, no. 3, (1990), pp. 8-9; Spiro, 'Taking Foreign Policy Away from the Feds'.

86 N.S. Chinchilla, N. Hamilton and J. Loucky, 'The Sanctuary Movement and Central American Activism in Los Angeles', Latin American Perspectives, vol. 36, no. 6 (2009), pp. 101-126.

87 R. Bilder, 'The Role of States and Cities in Foreign Relations', American Journal of International Law, vol. 83 (1989), pp. 821-831.

88 A. Klotz, 'Norms Reconstituting Interests'.

$89 \quad$ K. Pfordresher, 'US Cities, South African Apartheid: Where Do We Stand?', Bulletin, vol. 3, no. 3 (1989), p. 37 . 
Over 100 US cities divested billions of dollars in assets from firms doing business in Apartheid South Africa. ${ }^{90}$ City, county and state governments placed sanctions on and refused to provide loans to companies that did business with South Africa, and implemented selective purchasing policies prohibiting local-government contracts with South African firms. ${ }^{91}$ By 1990, there were 59 cities, as well as several states and counties, that had enacted some type of legislation banning investments in South Africa, incurring the sale of almost US $\$ 450$ billion in stocks and bonds, with the overall objective being to end Apartheid by forcing American corporate withdrawal from South Africa. ${ }^{92}$ Among the cities codifying and enforcing universal non-discrimination norms, several used the 'Sullivan Principles' as a guideline, fashioned in name after the Nuremburg Principles. Reverend Leon Sullivan, a Baptist minister and member of General Motors' Board of Directors, collaborated with business leaders to create the 'Sullivan Principles', a voluntary corporate code of conduct intended to improve the working conditions of black South Africans employed by US companies operating in South Africa to meet minimum standards of non-discrimination, which was in place from $1977-1987 .{ }^{93}$ Several US cities and other institutional investors structured divestment programmes around the Sullivan Principles, agreeing not to divest from companies that signed the Sullivan Principles, ${ }^{94}$ including New York City's Employee Retirement System. ${ }^{95}$

From the federal side, the multi-level dynamics surrounding the municipal foreign policy of divestment hinged less on purely legal argumentation than on ethical boundaries being pushed to their limits. In a 1989 US Senate meeting, Senator Jesse Helms threatened to punish US cities that divested from South Africa by denying them federal transportation funds. Yet even Transportation Appropriations Committee chair Frank Lautenberg recognized that 'financial concerns must at some point yield to moral standards. This is such a point'. ${ }^{96}$ Further illustrating this was New York Senator Daniel Moynihan's comment:

\footnotetext{
9o Shuman, 'Dateline Main Street'.

91 E. Fry and P.K. Kresl, The Urban Response to Internationalization (London: Edward Elgar, 2005).

92 Spiro, 'Taking Foreign Policy Away from the Feds'; G. Stevenson, 'The Complete Return on Investment', New York Times (25 March 1990); and Investor Responsibility Research Center, Divestment Action Roundup (May 1990).

93 Klotz, 'Norms Reconstituting Interests'.

94 P. Arnold and T. Hammond, 'The Role of Accounting in Ideological Conflict: Lessons from the South African Divestment Movement', Accounting, Organizations and Society, vol. 19, no. 2 (1994), pp. 111-126.

95 E.I., Koch, 'Cities, States Can't Ignore Apartheid', The Wall Street Journal (13 October 1986), p. 13 .

96 Swaim, 'Feds on Offense?', p. 23.
} 
From the day this Union of States was formed, we have found that citizens, communities, states, feeling strongly about moral or ethical issues in world affairs, have made their position clear, and have undertaken actions that affect them and them alone. Often, we have found that, with time, as we are seeing, those views spread. They gain ascendancy, and policy rises from the grassroots of the nation to the nation's capital. ${ }^{97}$

The outspoken critic of municipal foreign policy, Peter Spiro, argued that in enacting anti-South Africa legislation, cities 'assert a right, if not strictly speaking a purpose, to add a moral dimension to their actions as market participants.' ${ }^{98}$ Indeed they did. As the Bulletin reported, city-government leaders in Tallahassee, Florida, divested from South Africa, saying that they do want the economic growth opportunities that come from doing business with South Africa, 'but not at any price. ${ }^{99}$ In world society theoretical terms, the federal government's lack of sufficient anti-Apartheid measures constituted nationstate failure to enforce universal non-discrimination norms, thus prompting local authorities to codify and enforce those norms through divestment efforts. The chief outcome of these interventions by cities was quantifiably raising the costs to the South African economy of continuing Apartheid policies, although the precise impact that this pressure had on the risk calculus of South African leaders is uncertain.

\section{Discussion and Conclusion}

Exposure of city-level actors to universal norms and to narratives of norm violation, local legal autonomy, and the political alignment of constituents and local officials are the conditions associated with all three cases of municipal foreign policy discussed in this article. One potential alternative to the normative forces assumed by the world society interpretation would be an interestbased explanation, in which city-level actors intervene in foreign affairs to pursue financial or other material interests. However, all three cases involved the distinct risk of legal and monetary reprisals from the federal government, as well as direct economic opportunity costs (divestment from South Africa) and the material costs of sending aid (Central America). This helps to eliminate

\footnotetext{
97 Swaim, 'Feds on Offense?'.

98 P.J. Spiro, 'State and Local Anti-South Africa Action as an Intrusion upon the Federal Power in Foreign Affairs', Virginia Law Review, vol. 72, no. 4 (1986), p. 824.

99 J. McLean, 'Divestiture: One City's Experience', Bulletin, vol. 3, no. 1 (1988), p. 8.
} 
an alternative interest-based explanation, lending support to the normative forces posited by world society theory.

The municipal foreign-policy movement was a coming of age for the global 'actorhood' of US city governments. A theoretical synthesis of world society, diplomatic studies and social movement theory literature that advances our understanding of the normative dynamics behind city diplomacy can be described as follows. Noé Cornago and Alexander Kuznetsov, respectively, recognize that local governments can be motivated to intervene in foreign affairs because of norm-driven ambitions ${ }^{100}$ and in response to inefficacy by the nation-state ${ }^{101}$ but the world society approach reveals that the former can drive the latter within a larger macro-sociological context. Per world society theory, the United States itself is a prominent source and rapid adopter and enforcer of world society norms, ${ }^{102}$ meaning that US cities are highly exposed and likely to adopt and enforce these norms relative to other national contexts. In these conditions, a nation-state's failure to enforce or violation of these norms can lead to local attempts to enforce conformity to them. ${ }^{103}$ Accordingly, as rapid adopters of the world society norms of safety, human rights and racial equality, US cities responded to US federal failures and violations in the arms race, the Central American crisis and Apartheid in South Africa by using municipal foreign policy to codify and enforce conformity to those norms. While new social movement theory attributes this universalistic activism taking hold in the United States to the advanced post-industrial quality of the nation's society, ${ }^{104}$ world society theory offers a more macro-sociological explanation of the national context, where relative embeddedness in and connectivity to world culture influence such outcomes. ${ }^{105}$

Regarding the political nature of the national context, authoritarian or otherwise non-democratic systems would significantly stymy or entirely preclude municipal foreign policy, thus the United States' democratic context allowed sufficient political and legal autonomy for cities to challenge the federal government, ${ }^{106}$ with the Tenth Amendment playing a particularly crucial role. While city diplomacy was accelerated by the decentralization associated with new federalism, more crucial was the process outlined by Kristin Ljungkvist of

\footnotetext{
100 Cornago, Plural Diplomacies.

101 Kuznetsov, Theory and Practice of Paradiplomacy.

102 Drori, 'Governed by Governance'; and Meyer, 'World Society, Institutional Theories'.

103 Meyer et al., 'World Society and the Nation-State'.

104 Hegedus, 'Social Movements and Social Change in Self-Creative Society'.

105 Drori, 'Governed by Governance'; and Meyer, 'World Society, Institutional Theories'.

106 Alger, 'World Relations of Cities'; Bursens and Deforche, 'Going Beyond Paradiplomacy?'; and Tavares, Paradiplomacy.
} 
local identification with, interest formation on and official intervention in the global community. ${ }^{107}$ However, whether this process can occur and whether it can result in official municipal action is largely dependent upon theoretical conditions explained in social movement theory. The first requirement is the communication of narratives concerning social issues that resonate with local activists, per framing theory. ${ }^{108}$ The cities where these narratives reach can have crucial dialogue between local officials and constituents on said issues which, as Ljungkvist describes, can result in the decision by local officials to intervene in global affairs. ${ }^{109}$ Whether this decision actually occurs in favour of intervention is, as suggested by the political process theory of social movements, dependent upon whether local officials and constituents align politically on the issues. ${ }^{110}$ Framing narratives are likely to reach larger and better connected cities more rapidly, and political alignment between local officials and constituents on global issues likely occurs in cities with a history of peace activism. In sum, this synthesis of diplomatic studies, social movement theory and world society theory allows each to fill mutual explanatory gaps concerning the contexts of the US legal system, social movement dynamics, participation versus non-participation in foreign affairs, and the macro-sociological normative processes underpinning the US municipal foreign-policy movement.

The normative, political and economic role of cities on the world stage has metastasized since the 1980s, and the theoretical synthesis presented here for the municipal foreign-policy movement can be applied to the contentious city-diplomacy dynamics occurring in the United States today. Since the inauguration of US President Trump, a slew of American cities have declared themselves sanctuary cities for undocumented immigrants and refugees in response to Trump's executive orders on immigration; several US locales have launched legal challenges to Trump's temporary travel ban from seven majority-Muslim countries; and a growing number of US cities have recommitted to the Paris Climate Agreement in response to Trump's announcement of the United States' federal intent to withdraw. Not all US cities are participating in these interventions, but those that are can be posited to satisfy the same theoretical conditions as those in the municipal foreign-policy movement, as discussed

\footnotetext{
107 Ljungkvist, The Global City 2.o.

108 Nepstad, 'Creating Transnational Solidarity'; and Snow and Benford, 'Ideology, Frame Resonance and Participant Mobilization'.

109 Ljungkvist, The Global City 2.o.

110 Miller, 'Political Empowerment, Local-Central State Relations, and Geographically Shifting Political Opportunity Structures'; and McAdam, 'Political Process Theory'.
} 
above. While extensive, the collective theoretical framework presented here is still incomplete.

Future research on politically contentious city diplomacy in democratic countries should apply this theoretical framework, but should also build further upon it with additional explanatory variables beyond normative processes. Not least would be the variable of the economic capacity of cities and profit-seeking interests. That is, Cornago's concept of plural diplomacies describes not only normative factors, but also the pursuit of private capitalist interests as shaping the diplomatic arena, ${ }^{111}$ and some NFZ ordinances emphasized not just moral and normative concerns, but also the adverse local economic consequences of military contracting. ${ }^{112}$ This may necessitate an additional political-economic approach to further understanding the overtly political city diplomacy explored here, in both the historical and contemporary settings.

Benjamin Leffel is a Ph.D. candidate in the Department of Sociology at the University of California Irvine (UCI), a Kugelman Research Fellow for the Center for Citizen Peacebuilding at UCI, and holds an MA in International Affairs from the School of International Service at The American University. His research interests include city diplomacy, transnational city networks, global climate finance, urban climate action, US-China and Sino foreign affairs, global political economics and subnational affairs.

\footnotetext{
111 Cornago, Plural Diplomacies.

112 A. Donnay and H. Averbeck, 'Challenging the Nuclear Weapons Industry', Bulletin, vol. 2, no. 2 (1988), pp. 47-50.
} 